\title{
Updraft Gasifier-Stirling Engine Biomass Incineration System Power Generation
}

\author{
Krissadang Sookramoon \\ Faculty of Industrial Technology, Vallaya Alongkorn Rajabhat University, Klongluang, \\ Pathum Thani 13180, Thailand
}

(Corresponding author's e-mail: krissadangs@gmail.com)

Received: 22 September 2020, Revised: 10 May 2021, Accepted: 22 May 2021

\begin{abstract}
Biomass, the world's largest renewable energy source, will continue to grow in the following energy markets. As a result, small biomass conversion systems are more competitive than large stand-alone converters because most of the biomass sources have low energy density and are widely distributed in space. The current study offers a small solid biomass power generation system to examine the possibility of direct connection of updates fixed bed gasifiers and a Stirling engine. The fixed bed updraft gasifier uses a combustion burner built into the gasifier to completely burn the synthetic gas produced by the gasifier. The exhaust gases generated by the synthesis gas combustion in the combustion tube are directed to the Stirling engine heater head. The engine then converts the heat contained in the exhaust gases. Output depends on the heat input. And the heat input is proportional to the flue gas flow rate and temperature Preliminary studies on the proposed straight couplings of the energy derived from the gasifier to mechanical energy of $300 \mathrm{~mW}$ and electrical energy of $50 \mathrm{~mW}$. The outcomes of the Stirling engine with Updraft gasifier test shows that Pradauk biomass is more effective than charcoal biomass. Current research shows that no supplemental fuel is needed to keep the current system running smoothly. The technology and units presented can be considered as a viable solid biomass power generation system and enlarge to produce more electricity in rural areas of Thailand in the next step.
\end{abstract}

Keywords: Stirling engine, Updraft gasifier, Praduak wood chips, Charcoal, Engine performance

\section{Introduction}

The world's annual production of biomass energy is about 100 billion tons of coal. The world's annual energy consumption is seven times greater than this abundant energy of biomass [1]. Energy from plant biomass (not only from forests) is produced both conventionally (firewood) and modernly (e.g. ethanol and combined heat and power) in a renewable way, especially in developing countries. This is the greatest possible use of energy. Moreover, new technologies could significantly improve the efficiency of biomass energy use, and many areas of sustainable energy development will contribute to a quarter of the world's energy supply by 2025 [2]. The energy density of biomass is low and it is vast in space. Therefore, a small system would bring a small system to a biomass supplier instead of having to bear the transportation costs to deliver the biomass to a large central plant, which could result in a large standalone system. It is more competitive than the conversion plant. In addition, small-scale biomass power generation systems have advantages in terms of environmental impact and are distributed on site heat and power supply. Based on scale economies rather than large-scale biomass power generation systems, small-scale biomass power generation systems are simple in design and fully automated, processing various biomass sources in the market should be flexible. Stirling engines can run on a variety of heat sources and it is also called external combustion engine when the heat derived from fuel combustion is utilized, the engine is working. As an external combustion device and due to low demand operating conditions, the Stirling engine was included in research projects on the use of biomass energy as a viable engine [3-5]. Successful projects for biomass Stirling engines are limited to only a few demonstration projects for landfill gas carried out by STM Inc. [6]. When examining previous conversions [3-5] of solid biomass for energy projects, the Stirling engine was faced with lower system efficiency and higher operating costs. The low efficiency of the system is mainly due to inefficient gasification or combustion processes for solid biomass. Turbine inflows in syngas and unburned coils prevent integration of Stirling 
engines with converters of solid biomass to natural gases. Therefore, it was concluded that combustion can only occur in combination with a stocker boiler and steam turbine. Gasification of solid biomass can produce low carbon synthetic gaseous fuels. It is mainly adopted by various small biomass power systems. The resulting synthetic gases, consisting mainly of carbon monoxide and hydrogen, are cleaned before use in an internal combustion engine connected to a gas turbine or electric generator [7]. Waste heat from the turbine or engine can also be captured and directed for useful power generation applications. Unfortunately, all gasification processes produce very viscous and very acidic tars. Produced tars cause severe malfunctions and corrosion of transport and pipelines. Therefore, it is very difficult to collect or use synthetic gas without removing the tar. A complex de-tar system is an essential component for any type of gasification system. Water spraying is a common method to remove tar from synthetic gas. Removing tar from spraying water inadvertently produces more contaminated water. And, most importantly, it loses more than $50 \%$ of its energy in synthetic gas. Consequently, low calorific value synthetic gas may require supplementary fossil fuels to increase its heating value for constant combustion in a Stirling engine. The present study employs a modified updraft fixed bed gasifier developed by the present author to directly ignite the synthetic gas generated by biomass gasification inside the reactor. The heat emitted by the direct combustion of synthetic gas is transported to the heater head of the Stirling engine to produce high efficiency. The schematic of the direct coupling of the Updraft gasifier with the Stirling engine is shown in Figure 1. This direct integration of the gasifier and the Stirling engine is only possible when the gasifier produces large amounts of synthetic gas, especially at low temperatures and in special cases.

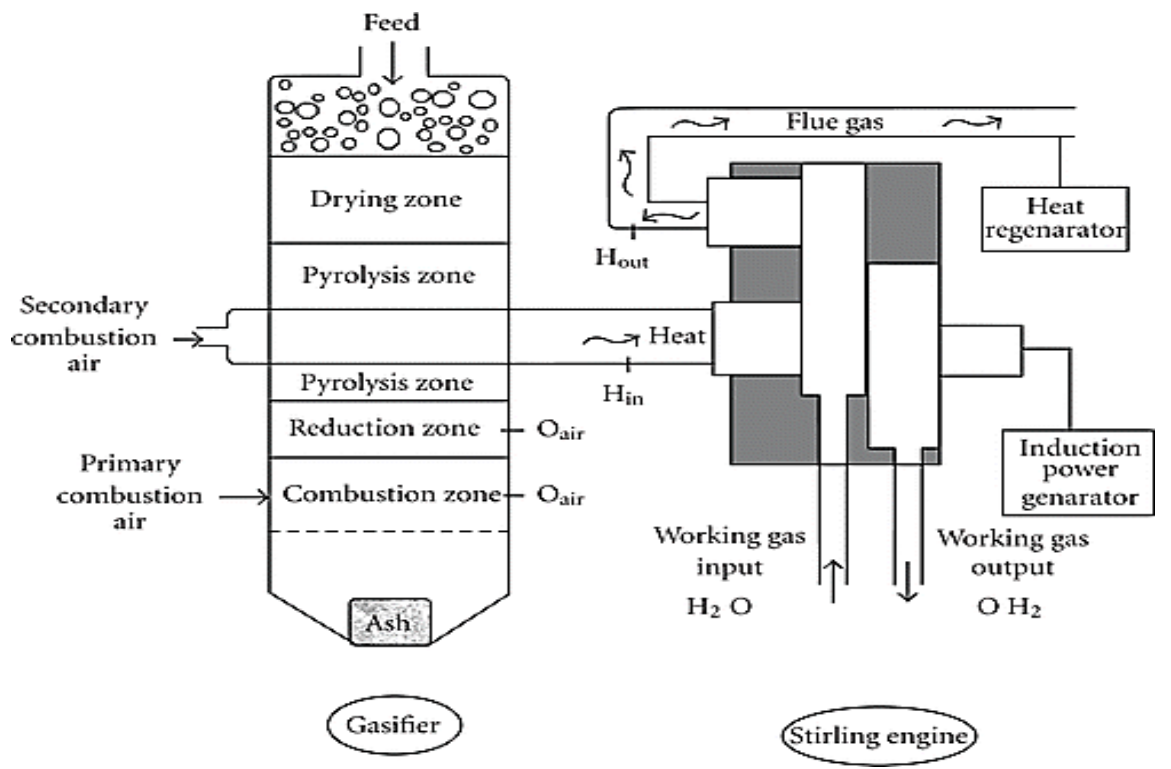

Figure 1 The diagram of the Stirling engine coupled with an updraft gasifier [8].

Actually, Stirling engines are not very popular, although they have a dominant position in the renewable energy technology. They are used as a power unit in solar dish collectors and convert solar energy with efficiency higher than photovoltaic. The most innovative Stirling engines at solar power technology are line ü-type engines with no rotating parts, line generator, no bearings and lubrication system and very long maintenance-free time [9]. Other typical, but still not very popular application of Stirling engine is a CHP biomass combustion plant (Figure 3). In Stirling engine over internal combustion engines, the heat is not supplied to the cycle combustion of the fuel inside the cylinder, but transferred from the outside through a heat exchanger. Consequently, the combustion system for a Stirling engine can be based on proven furnace technology, thus reducing combustion related problems typical of solid biomass fuels. The heat input from fuel combustion is transferred to the working gas through a hot heat exchanger at a high temperature typically between 680 and $780{ }^{\circ} \mathrm{C}[10,11]$. The temperature of the cooling water in a cold heat exchanger is $\left(25-75^{\circ} \mathrm{C}\right)$. 


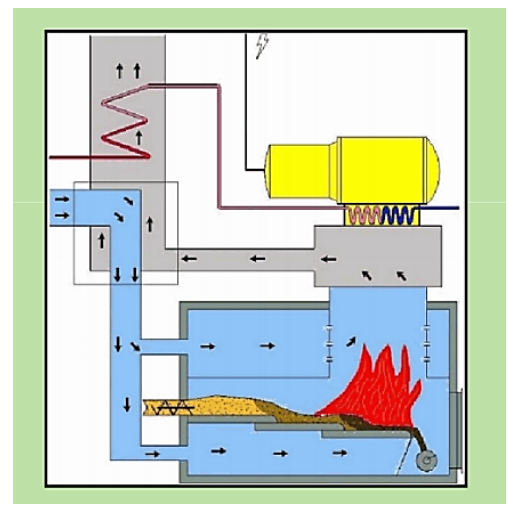

Figure 2 CHP biomass combustion plant with Stirling engine [12].

Many researchers have studied on the application of Stirling-biomass energy. Szewczyk, et al [13] carried out the application of biomass-powered Stirling engines. The features and examples of use of Cogenerative system based on Stirling engine are suggested. The properties of diverse kinds of renewable energy as sources of energy for small farms in Pod-karpackie province, Cogenerative biomass technologies have shown the most appropriate for its supplying. Distinctive resolutions based on direct combustion boiler attached with biomass-powered Stirling engine is the most motivating. Since the effectiveness of solicitation of renewable energy causes in agricultural farm numerous expectations should be made $[14,15]$. Masoud Rockni [16] studied thermodynamic and thermoeconomic analysis of a system with biomass gasification, solid oxide fuel cell (SOFC) and Stirling engine. The Stirling engine for small-scale combined gasification solid oxide fuel cell (SOFC) and combined heat and power (CHP) has been investigated thermodynamically with a net power of $120 \mathrm{~kW}$. Wood chips are used as gasification feedstocks for the production of syngas, which are then used to feed the anode side of the SOFC stack. Thermal efficiency of 0.424 LHV (lower heating value) is found in the plant to use $89.4 \mathrm{~kg} / \mathrm{h}$ feedstock per hour to produce the aforementioned energy. The power economy analysis shows that the power generation value is $0.1204 \mathrm{k} / \mathrm{kWh}$. In addition, hot water is considered a by-product, and the hot water price is found to be $0.0214 \mathrm{k} / \mathrm{kWh}$. Compared to other renewable systems of similar scales, this result shows that both SOFC and Stirling engine technology can deliver energy comparable costs to similar sized renewable. Damirchi, et al [17] conducted design, fabrication and evaluation of GammaType Stirling engine to produce electricity from biomass for the micro-CHP system and they found that maximum brake power output was obtained with helium at a $550{ }^{\circ} \mathrm{C}$ heat source temperature and $10 \mathrm{bar}$ charge pressure at $700 \mathrm{rpm}$ as $96.7 \mathrm{~W}$. Electrical energy produced from biomass sources. Sugarcane bagasse, wood, wheat straw, poplar wood and sawdust as fuel system were selected. Most power be obtained from the sawdust (46 watt) and pruning of trees for wood for low power (21 watts), respectively.

Therefore, the aim of this work is to test a small Gamma Stirling engine performance and to conduct the feasibility study of a small scale updraft gasifier-Stirling engine biomass incineration system power generation at our workshop. This small unit combines an updraft gasifier with a $300 \mathrm{~mW}$ Stirling engine attached to the generator. Test the speed of rotation and measure the electric current obtained from the small Gamma-type Stirling engine built. To analyze the system, the mathematical model of the engine analysis was analyzed. The system is described and the results are presented from this study.

\section{System description}

$300 \mathrm{~W}$ Stirling engine

In this work, A $300 \mathrm{~mW}$ gamma Stirling engine is manufactured by Milada Parts Company Limited, Pratum tani Province. Gamma Stirling engine is a heat engine in which the gas is the working medium, in which case the air is enclosed in the machine. In the combustion chamber, the engine part is kept at a constant high temperature by burning fuel or external heat flow. In contrast, the other side is kept at a constant ambient temperature. The working gas is moved back and forth between the hot and cold parts of the engine by the motion of the engine pistons. The mutual movement of the pistons is converted into a rotary motion by the swash plate driver, which is then generated by a power generator. The regenerator is used between the hot and cold parts of the engine to increase efficiency. This heat can be supplied to the engine by an external heat source or by burning various fuels. In the present study, synthesized gas from solid biomass is fired directly into the carburetor to produce sufficient heat flow to drive the engine. 


\section{Updraft fixed bed gasifier with combustor for biomass gasification and combustion}

This fixed bed-up flow gasifier is used in this study to ignite the condensate inside the reactor, to prevent the entire process of removing tar. The schematic diagram of the modified fixed bed gasifier used in this study is shown in Figure 3. The biomass feedstock is fed on top of the cylindrical reactor and the crate at the bottom of the reactor supports the reaction bed. The gasifier air enters the horizontal ring located at the top of the grinder along the inner wall of the gasifier through several small holes. The resulting horn is pushed into the underlying tube through several small holes in the bottom of the tube. The underlying pipe inside the flow gasifier serves 2 purposes: To provide secondary combustion air to fully condensate the condenser hose and condenser combustion chamber to exit the controller and apply heat and electricity. Release clean and hot flow gas. The biomass feed stock permanently seeps into the gas stream and passes through the drying zone, pyrolysis zone, recovery zone, and combustion zone. The biomass dry in a dry area. Biomass melt into fluctuating gas and solid coal in powerless areas. Pyrolysis and dehydration are mainly due to flow and partly by radiation from the combustion zone. Many reactions include areas with a decrease in carbon dioxide and water fever. Carbon is also converted, and carbon monoxide and hydrogen are produced as the main components of synthetic gas. The remaining char burns to provide heat to the combustion zone. The gasifier was supplied with wood chips, and in this study the gas was burned with embedded gas after the gasification process. The embedded combustor is a unique feature of this modified gasifier. Compactor provides a place to burn syngas directly inside the gasifier. During the intense combustion in the pipe, high temperatures are generated and maintained in the decomposition zone of the gasifier. Creating a hot thermal decomposition zone increases the overall gasification intensity, resulting in a more stable gasification process. Figure 4 shows a snapshot of a gasifier fed by combustion with wood chips and embedded combustion. The time history of the flame or flue gas temperature on the tube display is recorded. This combination of gasifier and embedded combustion has been shown to be able to produce concentrated combustion at a flue gas temperature of $1,320{ }^{\circ} \mathrm{C}$.

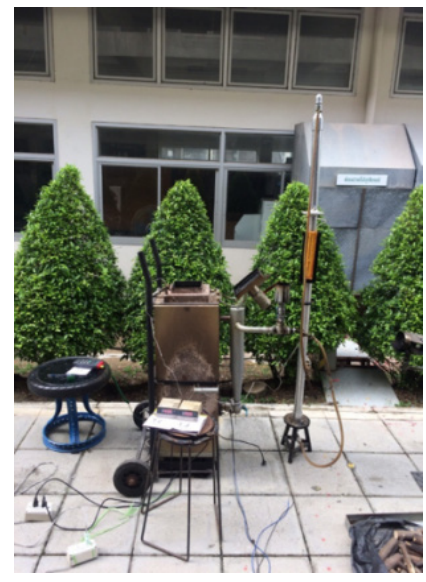

Figure 3 Fixed bed updraft gasifier test set.

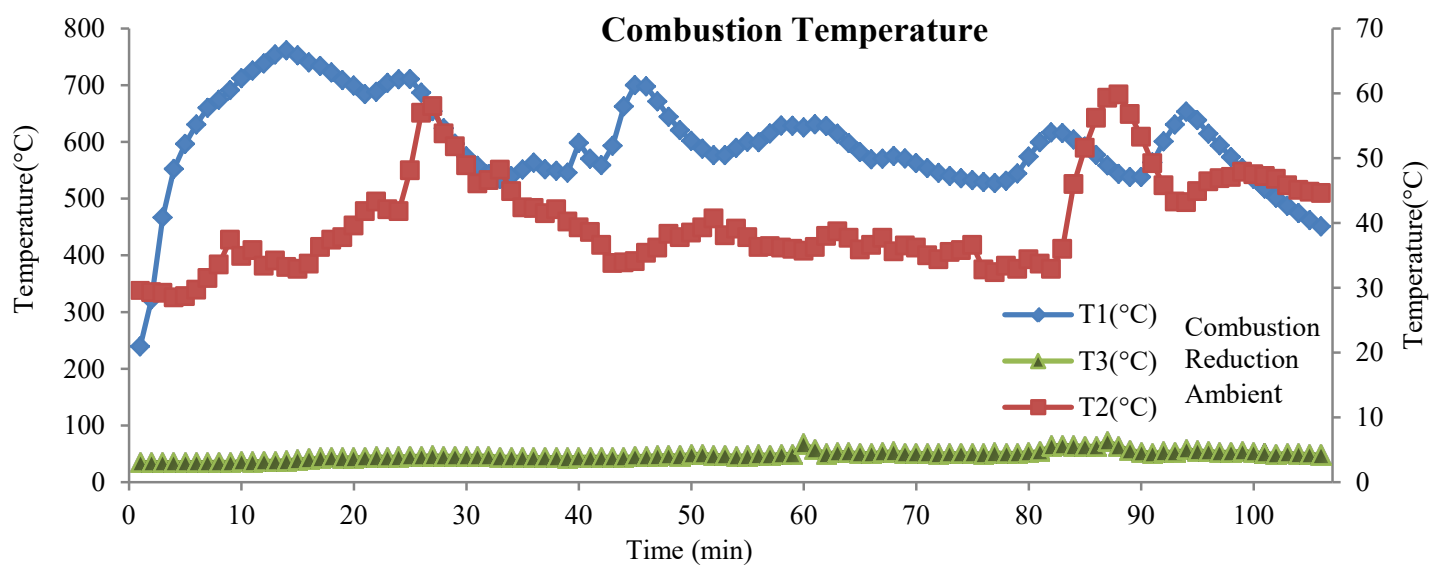

Figure 4 Represented flame temperature history at the exit of the combustor. 


\section{Integration of the gasifier with the $300 \mathrm{~mW}$ Stirling engine}

Gamma is achieved by direct contact of the embedded combustor with the gasifier, in the Stirling engine gas flow with the improved gasifier flanges combined with the Stirling engine. As a result, Figure 5 shows a snapshot of the Stirling -gasifier engine system, where a high temperature combustion gas flows into the Stirling engine inlet due to the synthesis of combustion gas in the combustion tube. Subsequently, the heat from the combustion gases is transferred to the heat exchanger next to the hot cylinder. The air working gas within the power cylinder is heated and expands to move the piston within the power cylinder. With the displacer, the working gas moves into the cold cylinder and heated with air by external cooling. In the present study, the air in the cold cylinder was adopted as the required cooling medium. In competition with other existing technology when using helium gas as a working fluid and hydrogen gas as a coolant for the engine cooling system would make more complicated and difficult to use in a rural area in maintenance.

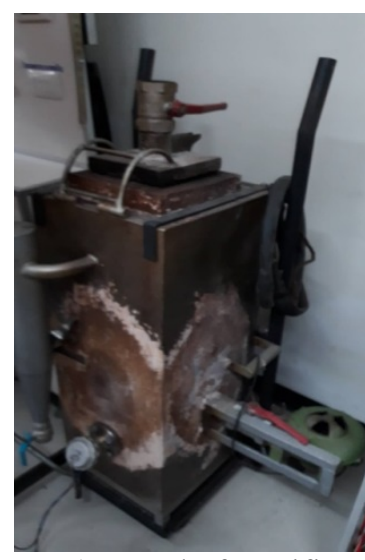

a) Updraft gasifier

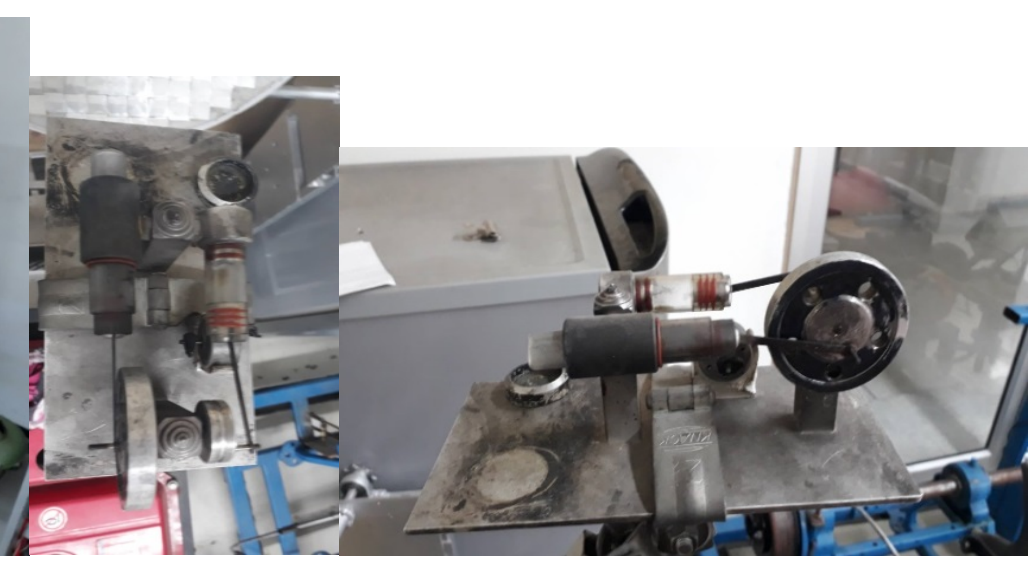

b) Gamma Stirling engine

Figure 5 Portrait of an updraft gasifier with a Stirling engine.

\section{Materials and methods}

\section{Preparation processes}

In the present study, several biomass resources are used to evaluate the performance of the proposed biomass gasfier Stirling engine system. The size of the biomass used ranges from 5 to $10 \mathrm{~cm}$ of charcoal Praduak wood chips. Moisture content up to $55 \%$ to weight shows no difficulty in operating the gasifier. Because of this deep combustion in the embedded combustion chamber, the sense of different combinations of materials starting the biomass, for example charcoal, Praduak wood chips, etc., or different combinations of materials starting the biomass does not make sense. The sensitivity of this system to different fuel systems is quite low, with the exception of large quantities of biomass feedstock such as waste paper. The exported wood waste has already been prepared at the resource wrestling plant. The biomass feedstock used in the present study is carefully measured. The average temperature value, moisture content, and ash content are determined by $11,633 \mathrm{~kg} / \mathrm{kg}(2,780.35 \mathrm{kcal}), 20 \%$ by weight, and $1.2 \%$ by weight, respectively.

\section{Measurement and observing system}

Typical temperatures inside the gasifier (combustion zone, reduction zone, pyrolysis zone, and synthetic gas combustion tube) and Stirling engine (flue gas inlet, flue gas exit, cooling air inlet, and cooling air exit) as shown in Figure $\mathbf{5}$ are measured by K-type thermocouples. Mass flow rate is measured by a pitot tube. A multifunction power meter is used to conduct power output measurement. 

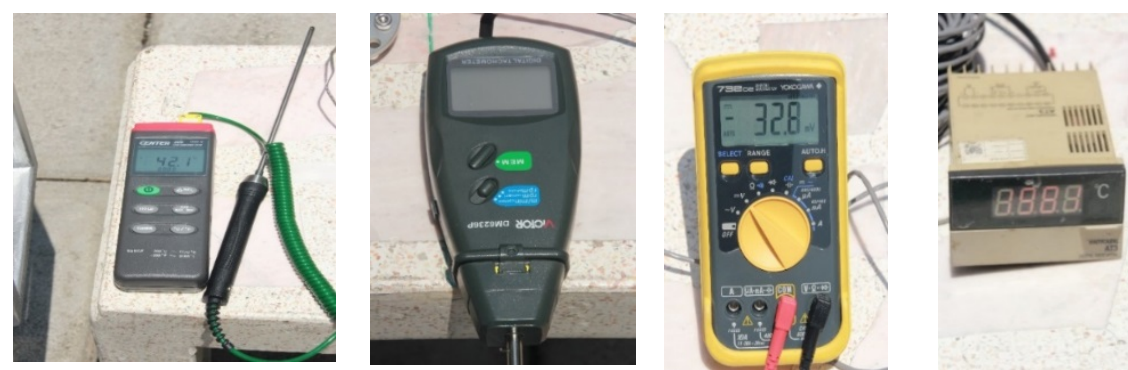

Figure 6 Portable Thermocouple (CENTER 304), Digital Tachometer (Victor DM 6236 P), Digital Multimeter (Fluke 789), and Temperature Display (Measuring input for Pt 1000 thermocouple).

\section{Operational process}

Direct coupling of the updraft gasifier with a gamma Stirling engine results in a simple operating process. After loading the gasifier with biomass, the bottom layer of biomass feedstock is ignited by the gas gun to start the gasification processes. In less than $15 \mathrm{~min}$ or when the synthetic gas temperature is around $300{ }^{\circ} \mathrm{C}$ each in the built-in combustion chamber, secondary air enters the combustion chamber and the synthesis gas is ignited automatically and burns sharply in the combustion chamber. Biomass flows easily on the chisel and the combustion chamber can maintain its steady combustion of synthetic gas without any auxiliary fuels throughout the process. The heat flows into the Stirling engine and initiates power generation processes without any control in the current study.

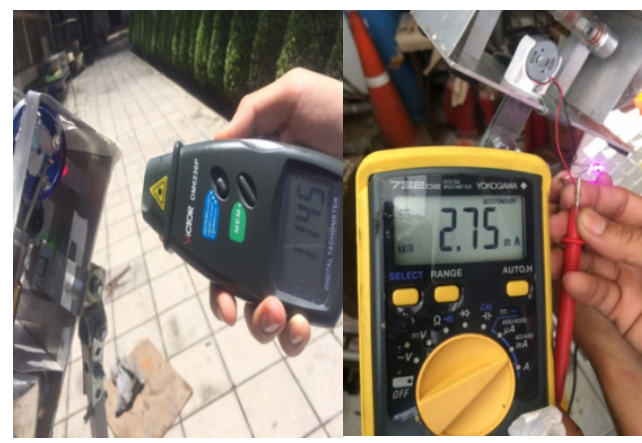

Figure 7 Updraft gasifier with the gamma Stirling engine results in the simple operation process.

The engine controller monitors the temperature of the engine heater head. When the temperature of the heating head reaches $350{ }^{\circ} \mathrm{C}$, the engine starts and turns on the generator by using a drive belt. The only interference step is the start-up step to ignite the gasifier, and the synovial will burn spontaneously in the built-in combustion chamber. In this case, the high temperature flue gas will raise the temperature of the heater tube to start the engine. After starting the engine, power will be generated automatically at the main frequency. The proposed system does not require additional fuel during all subsequent work processes. The $1^{\text {st }}$ step, a gas stove was used to start a Stirling engine with Pradauk wood and charcoal as fuel. Put Praduak wood into the hopper of the gas stove, then burn wood, waiting for syngas generation, ignite the gas from the end of the hose, then put the Stirling engine hot rod to receive the heat input derived from the biomass combustion. 


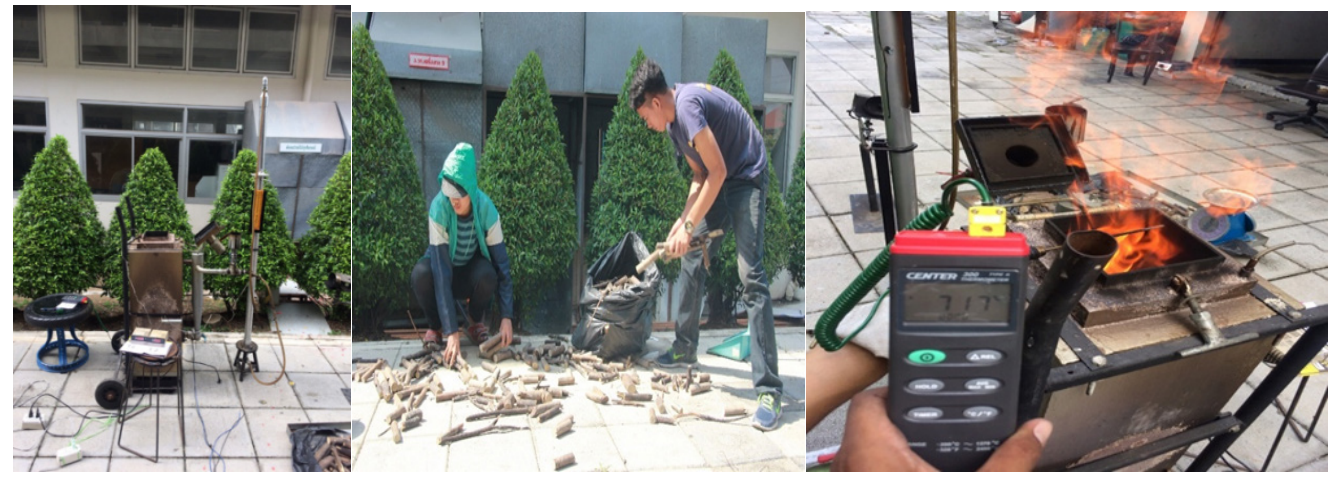

a) Updraft gasifier biomass loading

b) Biomass Combustion

Figure 8 Biomass Stirling engine experiment using mixed wood charcoal and Padauk wood chips as fuel.

\section{Results and discussion}

\section{Biomass Stirling engine}

In the biomass Stirling engine test used a gas stove to start the engine using Pradauk wood and mixed deciduous wood as fuel. This test will collect the combustion chamber temperature. Burner temperature Outlet gas temperature, outside air temperature, wind speed, current, voltage, engine speed.

$\mathrm{T}_{1}=$ Combustion chamber temperature $\mathrm{T}_{2}=$ Burner temperature $\mathrm{T}_{3}=$ Gas outlet temperature

Graph showing results of the Stirling engine biomass (Pradauk wood)

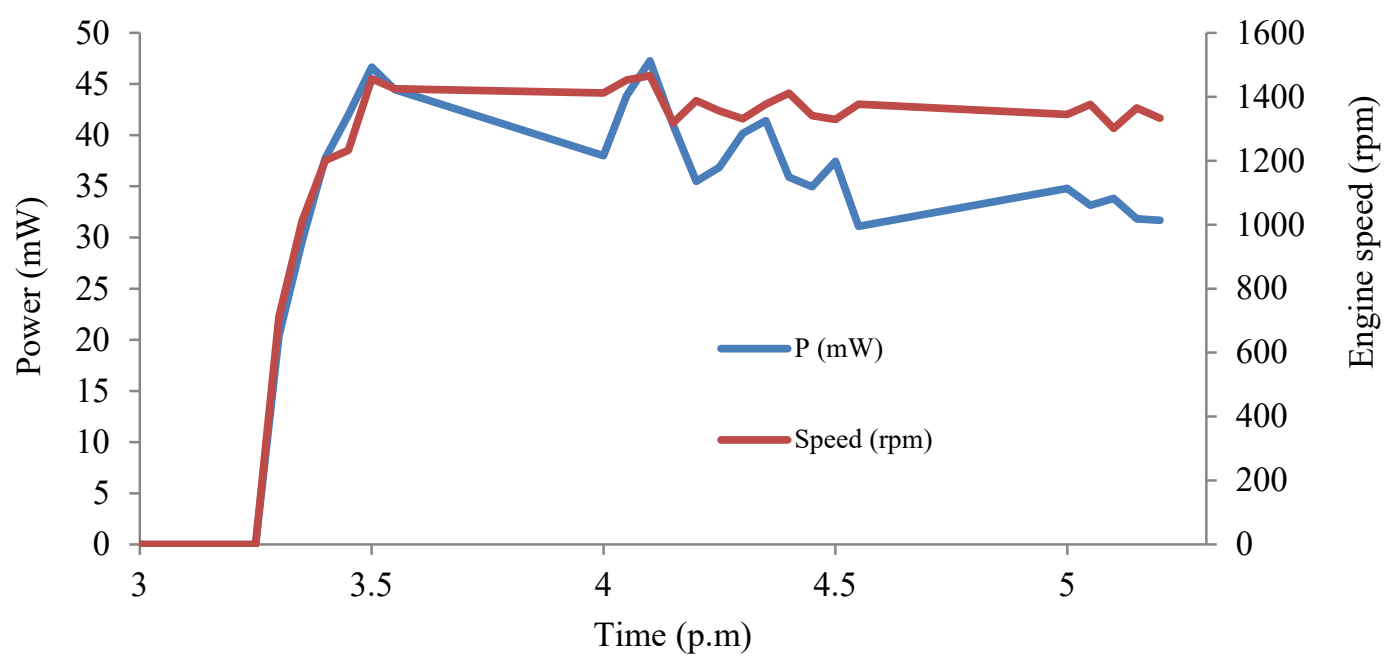

Figure 9 Engine speed and generator vs time used Pradauk wood fuel.

From the graphs it was found that the maximum combustion temperature was $784.3^{\circ} \mathrm{C}$ after 25 min and the gas start temperature was $731.3{ }^{\circ} \mathrm{C}$ after $30 \mathrm{~min}$. The engine speed was $1,466 \mathrm{rpm}$, the maximum current of $10.5 \mathrm{~mA}$, and maximum voltage $4.5 \mathrm{~V}$ at $4.10 \mathrm{p} . \mathrm{m}$. It had a maximum electrical power of 47.25 $\mathrm{mW}$. Graph showing results of the Stirling engine biomass. (Charcoal) 


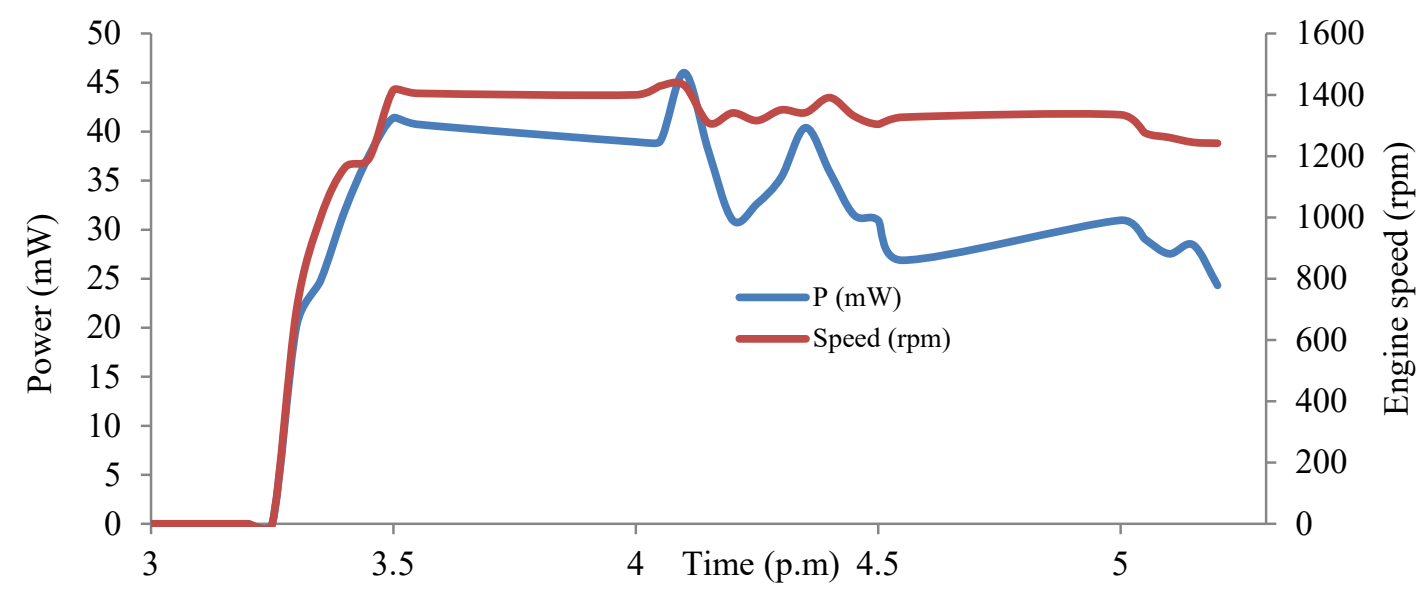

Figure 10 Engine speed and generator vs time used charcoal fuel.

From the graphs it was found that, the maximum combustion temperature was $710.7^{\circ} \mathrm{C}$ after 25 min and the gas start temperature was $731.3{ }^{\circ} \mathrm{C}$ after $30 \mathrm{~min}$. The engine speed was $1,431 \mathrm{rpm}$, the maximum current of $10.3 \mathrm{~mA}$, and the maximum voltage of $4.3 \mathrm{~V}$ at $4.10 \mathrm{p} . \mathrm{m}$. It has a maximum electrical power of 46.01 MW.

\section{Power measurements}

The engine starts after the temperature of the heating head has reached $699{ }^{\circ} \mathrm{C}$. The engine extracts and then converts the heat contained in the combustion gases into electricity. The output depends on the heat supply and is proportional to the flow rate and the temperature of the flue gas. The operating conditions are an engine cycle pressure of $15 \mathrm{MPa}$ at a heating head temperature of $700{ }^{\circ} \mathrm{C}$. In the current study, the combustion gas was generated and controlled in such a way that the temperature of the combustion gas in the Stirling heating head inlet of 699.1 and $731{ }^{\circ} \mathrm{C}$. This heat input rate is sufficient to generate the total power of $300 \mathrm{~mW}$. However, the measured power curve from the current study (Figure 11) was around 50 $\mathrm{mW}$.
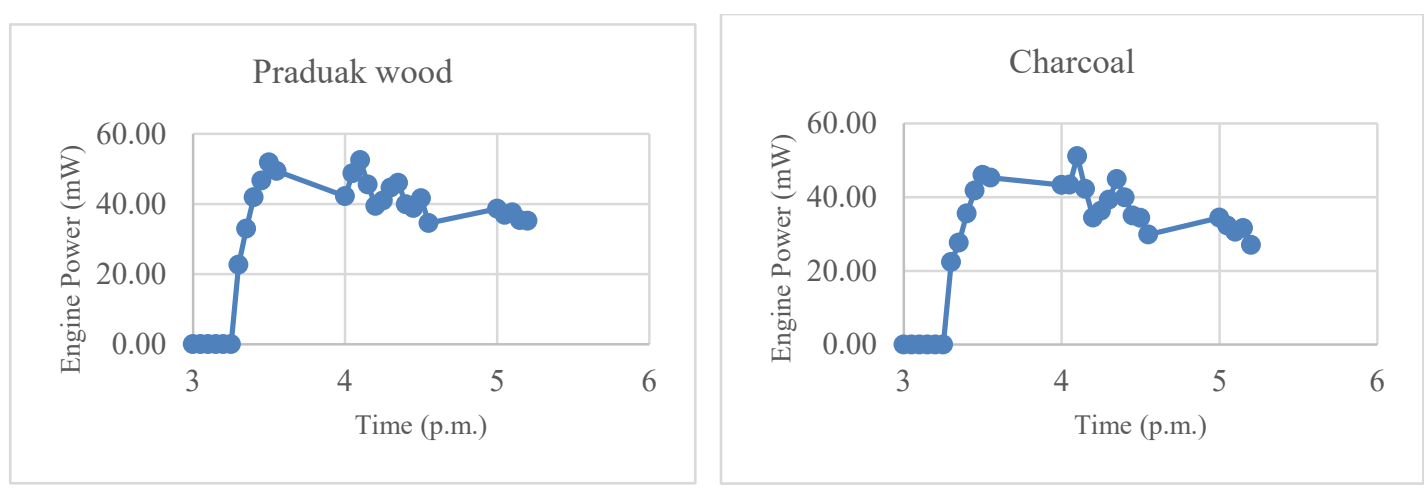

Figure 11 Power output histories from the Stirling engine.

\section{Schmidt analysis for Stirling engines [18]}

Work is done by the engine on the surroundings by virtue of the changing volumes of the working spaces Vc and Ve. The total work done by the engine is therefore the algebraic sum of the work done by the compression and expansion spaces. Over a complete cycle we get;

$$
\begin{aligned}
& \mathrm{W}_{\mathrm{C}}=\oint p \mathrm{pV}_{\mathrm{C}}=\int_{0}^{2 \pi} \mathrm{p} \frac{\mathrm{dV} \mathrm{V}_{\mathrm{C}}}{\mathrm{d} \theta} \mathrm{d} \theta \\
& \mathrm{W}_{\mathrm{e}}=\oint \mathrm{pdV}_{\mathrm{e}}=\int_{0}^{2 \pi} \mathrm{p} \frac{\mathrm{dV} \mathrm{V}_{\mathrm{e}}}{\mathrm{d} \theta} \mathrm{d} \theta
\end{aligned}
$$


$\mathrm{W}=\mathrm{W}_{\mathrm{C}}+\mathrm{W}_{\mathrm{e}}$

Eq. 3 is the 'equation of the caloric line' and has essentially the same form as that derived by Schmidt. The maximum and minimum values of pressure are easily evaluated for the extreme values of $\cos \varnothing$ :

$$
\begin{aligned}
& P_{\text {max }}=\frac{M R}{s(1-b)} \\
& P_{\text {min }}=\frac{M R}{s(1+b)}
\end{aligned}
$$

The average pressure over the cycle is set by

$$
\mathrm{P}_{\text {mean }}=\frac{1}{2 \pi} \int_{0}^{2 \pi} \mathrm{pd} \emptyset=\frac{\mathrm{MR}}{2 \pi \mathrm{s}} \int_{0}^{2 \pi} \frac{1}{(1+\mathrm{bcos} \varnothing)} \mathrm{d} \emptyset
$$

The engine calculation is shown in Figure 12 as follows [19];

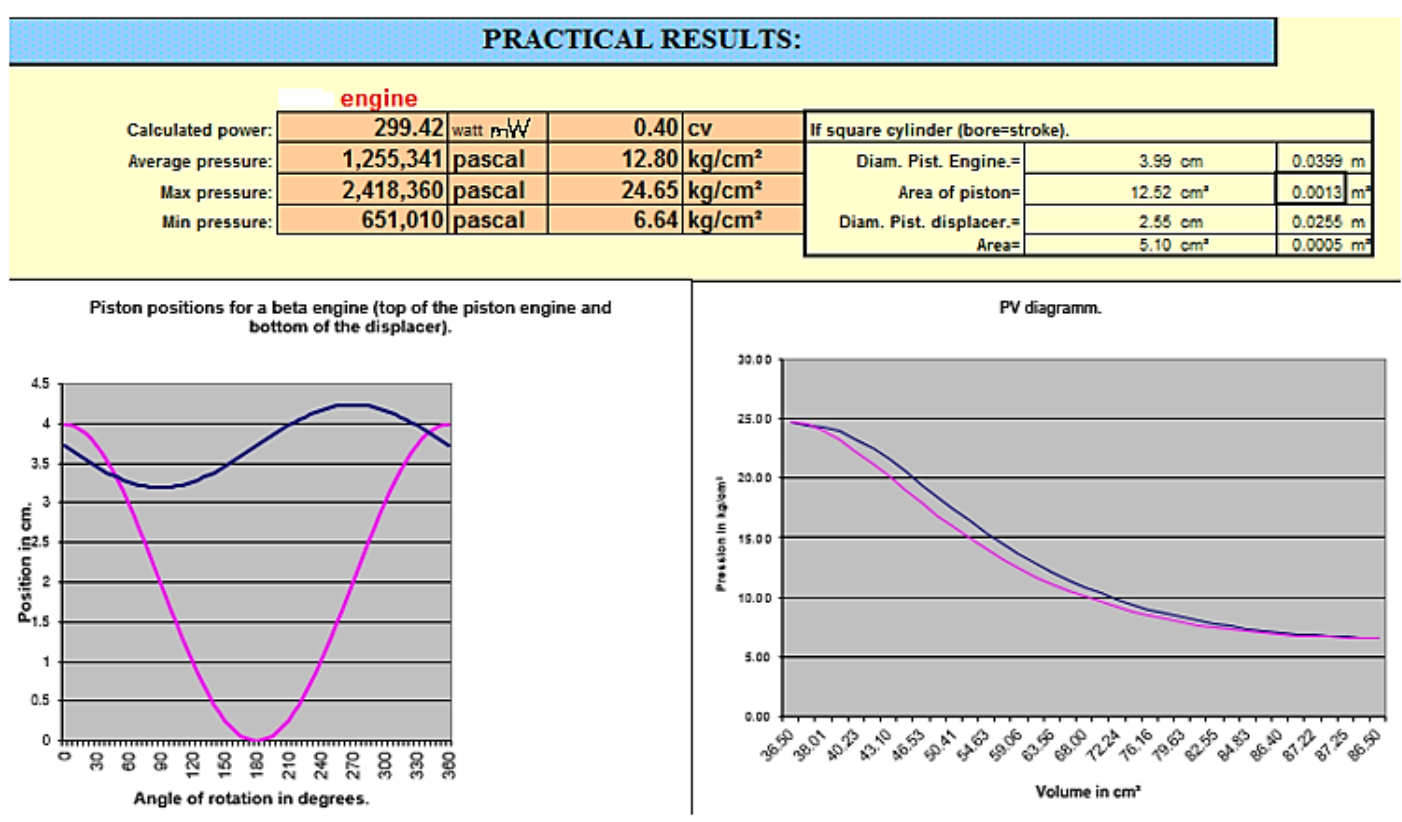

Figure 12 The Stirling engine calculation.

In Figure 12, the average pressure is $1.25 \mathrm{MPa}$ and the maximum pressure is $2.41 \mathrm{Mpa}$. The engine power, which has done in the surroundings is approximate $300 \mathrm{~mW}$.

\section{Overall performance}

The flue gas enters the heater head of the Stirling engine. The difference is created by the flow rate at least as much as possible in the flow gas. Current studies show that the proposed system is technically feasible because it can generate electricity without interference so as to maintain an almost stable process. Furthermore, updraft gasifier does not require any auxiliary fuels to convert the solid biomass feedstock environmentally efficiently to bounce gas at high temperatures. Feasibility can be expected. The Stirling engine that emits lower gas is still at a higher temperature and has a higher level of thermal energy, so adding a waste boiler to this system will significantly increase the overall rate of energy consumption. Improvements to the current system performance will be explored in future studies by selecting both waste heat boilers and suitable automatic biomass feeders. 


\section{The results of the biomass Stirling engine}

1. Pradauk biomass test on June 14, 2019 found that the maximum combustion temperature was $784.3{ }^{\circ} \mathrm{C}$ after $25 \mathrm{~min}$ and the gas formation temperature was $731.3^{\circ} \mathrm{C}$. After $30 \mathrm{~min}$, the Stirling engine had a maximum speed of 1,466 rpm, a maximum current was $10.5 \mathrm{~mA}$, and a voltage of $4.5 \mathrm{~V}$ at 4.10 P.M. It had a greater power of $47.25 \mathrm{~mW}$.

2. The consequences of the biomass Stirling engine (wood charcoal) on June 15, 2019 originate that the maximum temperature of the combustion zone was $710.7^{\circ} \mathrm{C}$ after $25 \mathrm{~min}$ and the gas formation temperature was $699.1^{\circ} \mathrm{C}$. After $30 \mathrm{~min}$, the Stirling engine had a maximum speed of 1,431 rpm, a maximum current of $10.3(\mathrm{~mA})$, and a voltage of $4.3 \mathrm{~V}$ at 4.10 P.M. The maximum power was 46.01 $\mathrm{mW}$.

\section{Conclusions}

In a current study, a fixed bed updraft gasifier has been successfully applied to a Ganmma Stirling engine for testing power generation. Praduak wood and charcoal were used as biomass feedstock for combustion testing. A fixed-bed gasifier with an integrated combustion chamber can transform solid biomass raw materials into high-temperature flue gas with low solid content. This energetic combustion in the system's built-in combustion chamber makes this system very insensitive to various fuel compositions, except for high water content biomass feedstocks. The Stirling engine extracts the heat converted from solid biomass and automatically converts it into electricity. According to the results of the Stirling engine test, Pradauk biomass is more efficient than charcoal biomass. Observation of the speed of the Stirling engine that can spin the engine flywheel, which produced more electric power. When the cylinder is heated, it causes the air expansion in the cylinder and the rotation of the flywheel, which converts thermal energy into mechanical energy and then to electrical energy, respectively. The temperature difference between the hot and cold side of the cylinder affects the speed of the engine. The higher engine rotational speed, the more electricity can be produced, which generated electric current between 0.3 - 1.7 Ampere. In the experiment, while burning Pradauk biomass in the updraft gasifier, it produced more smoke than burning charcoal because of moisture in the wood. In promoting the use of biomass energy in rural area can be substituted the use of fossil fuel, which is now deprecated. Moreover, biomass contain much lower sulfur than fossil fuels. That means using biomass will reduce the likelihood of occurrence at the "Greenhouse Effect" which is contrary to use oil in the transport sector or coal in a power plant.

\section{References}

[1] W Hatje and M Ruhl. Use of biomass for power- and heat-generation possibilities and limits. Ecol. Eng. 2000; 16, 41-9.

[2] D Hall. Biomass energy in industrialized countries-a view of the future. For. Ecol. Manag. 1997; 91, 17-45.

[3] HN Carlsen, N Ammundsen and J Traerup. $40 \mathrm{~kW}$ Stirling engine for solid fuel. In: Proceedings of the $31^{\text {st }}$ Intersociety Energy Conversion Engineering Conference, Washington, DC, USA. 1996, p. 23-34.

[4] N Jensen and J Werling. CHP from updraft gasifier and Stirling engine. In: Proceedings of the $12^{\text {th }}$ European Biomass Conference, Amsterdam, The Netherlands. 2002, p. 131-49.

[5] N Lane and W Beale. Micro-biomass electric power generation. In: Proceedings of the 3rd Biomass Conference of the America, Montreal, Canada. 1997, p. 83-104.

[6] STM Power Inc. STM Power Unit Model 4-260 Landfill Gas. 2005, Available at: http://www.stmpower.com/Markets/Landfill\%20Gas\%20Brochure.pdf, accessed September 2020.

[7] E Scoditti and N Barker. Thermal gasification of biomass 2001-2003, task 33 of IEA bioenergy agreement. IEA Bioenergy, 2004.

[8] JC Lin. Development of an updraft fixed bed gasifier with an embedded combustor fed by solid biomass. J. Chin. Inst. Eng. 2006; 29, 557-62.

[9] JH Leu. Biomass power generation through direct integration of updraft gasifier and stirling engine combustion system. Adv. Mech. Eng. 2010; 2, 1-7.

[10] Application of Biomass-powered Stirling Engines in Cogenerative systems, Available at: http://www.inPniacorp.com/., accessed September 2020.

[11] J Vos. Biomass Energy for Heating and Hot Water Supply in Belarus 2004, Available at: http://energoeffekt.gov.by, accessed September 2020. 
[12] Gasification in Stirling Engine Applications, Available at: http://www.stirling.dk, accessed September 2020.

[13] M Szewczyk and T Trzepieciński. Application of biomass-powered Stirling engines in cogenerative systems. Econtech. An Int. Quart. J. 2012; 01, 53-6.

[14] W Niemiec and M Szewczyk. Mo liwo ci wyko-rzystania odnawialnych ródeá energii w Województwie Podkarpackim, Budownictwo Przemysáowe, Energoosz-cz dnoĞ , Nr 1. 2010; 6, 11-4.

[15] W Niemiec, F Stachowicz, M Szewczyk and T Trze-pieci ski. Analiza mo liwo ci kompleksowego wykorzystania OZE w gospodarstwie agroturystycznym. Zeszyty Naukowe Politechniki Rzeszowskiej, Budow-nictwo I In ynieria ĝrodowiska. 2010; 57, 357-65.

[16] M Rockni. Thermodynamic and thermoeconomic analysis of a system with biomass gasification, solid oxide fuel cell (SOFC) and Stirling engine. Energy 2014; 76, 19-31.

[17] H Damirchi, G Najafi, S Alizadehnia, B Ghobadian, T Yusaf and R Mamat. Design, fabrication and evaluation of gamma-type stirling engine to produce electricity from biomass for the micro-CHP system. Energ. Proc. 2015; 75, 137-43.

[18] SCHMIDT ANALYSIS FOR STIRLING ENGINES, Available at: https://www.ohio.edu/mechanical/ stirling/isothermal/Schmidt.pdf, accessed September 2020.

[19] Jean-Pierre Vandormael Isothermic Calculation of a Stirling Engine: Alpha, Beta or Gamma, Available at: http://www.moteurstirling.com/pdf/calculuk.xls, accessed September 2020. 